\title{
ASSESSMENT OF CULTURABLE BACTERIA ASSOCIATED WITH FINE PARTICULATE MATTER COLLECTED IN ANTIOQUIA COLOMBIA- SOUTH AMERICA
}

Evaluación de las bacterias cultivables asociadas con partículas finas colectadas en el aire de Antioquia Colombia - Sudamérica

\author{
Duvan Alexander NANCLARES CASTAÑEDA ${ }^{1,2,3}$, Carmen Helena ZAPATA SÁNCHEZ ${ }^{2}$, \\ Lina Marcela SILVA-BEDOYA ${ }^{1}$, Olga Inés MONTONTOYA CAMPUZÁNO ${ }^{3}$ and \\ Claudia Ximena MORENO HERRERA ${ }^{1 *}$
}

\author{
${ }^{1}$ Grupo de Microbiodiversidad y Bioprospección, Escuela de Biociencias, Facultad de Ciencias, Universidad \\ Nacional de Colombia, sede Medellín, Carrera 65 No. 59A - 110, Medellín, Colombia \\ ${ }^{2}$ Departamento de Geociencias y Medioambiente, Facultad de Minas, Universidad Nacional de Colombia, sede \\ Medellín, Carrera 65 No. 59A - 110, Medellín, Colombia \\ ${ }^{3}$ Laboratorio Microbiología de Aguas y Alimentos, Universidad, Nacional de Colombia Carrera 65 No. 59A- \\ 110, Medellín, Colombia \\ *Corresponding author: cxmoreno@unal.edu.co
}

(Received: November 2018; accepted: September 2019)

Key words: bioaerosols, bacterial diversity, $\mathrm{PM}_{2.5}$, air pollution

\begin{abstract}
In recent years, air pollution in urban and rural environments has been increasing and is one of the factors of greatest public health concern. $\mathrm{PM}_{2.5}$ particulate matter is one of the main pollutants that deteriorate air quality. This particulate matter can carry bioaerosols as bacteria and fungi. Due to its size or aerodynamic diameter of less than $2.5 \mu \mathrm{m}$, it can be inhaled to the pulmonary alveoli, which is strongly associated with a rise in mortality and morbidity in exposed populations. In this research, the presence of bacteria associated with the $\mathrm{PM}_{2.5}$ fraction of particulate matter was evaluated in two urban areas (Urban-C and Urban-NW) and one rural area (Rural-N) from the Aburrá Valley (Antioquia, Colombia South America). In recent years, this region has been presenting high concentrations of $\mathrm{PM}_{2.5}$, exceeding several times the daily permissible limits $(50 \mu \mathrm{g} / \mathrm{m} 3)$ for this air pollutant. The isolation, characterization and identification of bacteria associated with $\mathrm{PM}_{2.5}$ was performed by culture-dependent techniques, molecular characterization by ribosomal intergenic spacer analysis (RISA) and $16 \mathrm{~S}$ rDNA sequencing, respectively. The dominant phylogenetic affiliations of the bacteria were grouped into three phyla: Proteobacteria, Actinobacteria and Firmicutes. The phylum Firmicutes dominated in all sampling points with several genera such as Bacillus, Staphylococcus, Paenibacillus, Lysinibacillus, Exiguobacterium and Macrococcus. Some species of these genera have been linked to pathogenicity in plants, animals and humans. Additionally, a greater presence of possible pathogenic microorganisms in urban areas was estimated, probably influenced by the concentration of $\mathrm{PM}_{2.5}$ and environmental conditions. These results provide important information to understand the distribution and ecology of airborne bacteria and demonstrate that the atmosphere in Colombia (Aburrá Valley) harbors bacteria that are clearly an important, but understudied, component of air quality that needs to be better integrated to the public health perspective.
\end{abstract}

Palabras clave: bioaerosoles, diversidad bacteriana, $\mathrm{PM}_{2.5}$, contaminación del aire 


\section{RESUMEN}

En los últimos años, la contaminación del aire en entornos urbanos y rurales ha aumentado y es uno de los factores de mayor preocupación para la salud pública. Las partículas $\mathrm{PM}_{2.5}$ son uno de los principales contaminantes que deterioran la calidad del aire. Este material puede transportar bioaerosoles como bacterias y hongos debido a su tamaño o diámetro aerodinámico de menos de $2.5 \mu \mathrm{m}$. Puede inhalarse hasta los alvéolos pulmonares, lo que está fuertemente asociado con un aumento de la mortalidad y la morbilidad en las poblaciones expuestas. En esta investigación se evaluó la presencia de bacterias asociadas con la fracción de partículas $\mathrm{PM}_{2.5}$ en dos áreas urbanas (Urban-C y Urban-NW) y una zona rural (Rural-N) del Valle de Aburrá (Antioquia, Colombia- Sudamérica). En los últimos años, esta región ha presentado altas concentraciones de $\mathrm{PM}_{2.5}$, superando varias veces los límites permisibles diarios $\left(50 \mu \mathrm{g} / \mathrm{m}^{3}\right)$ para este contaminante del aire. El aislamiento, la caracterización y la identificación de bacterias asociadas con $\mathrm{PM}_{2.5}$ se realizaron mediante técnicas dependientes del cultivo, la caracterización molecular mediante el análisis espaciador intergénico ribosomal (RISA) y la secuenciación de $16 \mathrm{~S}$ rADN, respectivamente. Las afiliaciones filogenéticas dominantes de las bacterias se agruparon en tres filos: Proteobacterias, Actinobacterias y Firmicutes. El filo Firmicutes dominó en todos los puntos de muestreo con varios géneros como Bacillus, Staphylococcus, Paenibacillus, Lysinibacillus, Exiguobacterium y Macrococcus. Algunas especies de estos géneros se han relacionado con patogenicidad en plantas, animales y seres humanos. Adicionalmente, se estimó una mayor presencia de posibles microorganismos patógenos en áreas urbanas, probablemente influenciados por la concentración de $\mathrm{PM}_{2.5}$ y las condiciones ambientales. Estos resultados proporcionan información importante para comprender la distribución y la ecología de las bacterias transportadas por el aire y demuestran que la atmósfera en Colombia (Valle de Aburrá) alberga bacterias que son claramente un componente importante, pero poco estudiado, de la calidad del aire que debe integrarse mejor en las perspectivas de la salud pública.

\section{INTRODUCTION}

The Aburrá Valley Metropolitan Area comprises 10 municipalities from the Antioquia department (Colombia, South America). It is a densely populated area, concentrated in a semi closed and narrow valley with diverse industrial activities and increasing urban development, number of cars and consumption of fossil fuels. All these activities release large quantities of pollutants to the atmosphere such as carbon monoxide, ozone, nitrogen oxides, sulphur oxides, volatile organic compounds and particulate matter that have an adverse effect on the air quality throughout the Aburrá Valley (Bedoya and Martinez 2009). Therefore, air pollution is a major threat to the health and quality of life of the population (Gaviria et al. 2011).

Particulate matter is classified according to its aerodynamic diameter in $\mathrm{PM}_{10}$ respirable particles $(<10 \mu \mathrm{m})$ and $\mathrm{PM}_{2.5}$ inhalable particles $(<2.5 \mu \mathrm{m})$ (WHO 2005). $\mathrm{PM}_{2.5}$ material is smaller and it can easily transport particles of biological origin (bioaerosols) on its surface such as pollen grains, virus, bacteria, and fungal and bacterial spores (Focil et al. 1999). This type of particles can reach the deepest parts of the lungs, sediment in the alveoli, be carried through systemic circulation, and enter other internal organs (Miller et al. 2007). This characteristic favors the development of acute respiratory infections, chronic respiratory diseases, cardiovascular diseases, lung cancer and even reproductive abnormalities (O'Neill et al. 2003, Pope and Dockery 2006). Usually the most affected are the sensitive groups such as children under five years old, immunosuppressed people, pregnant women and the elderly, constituting a major public health problem (Blanco 2003, WHO 2005).

Acceptable conditions for the proliferation and survival of microorganisms can be generated in the atmosphere because of the relative humidity, which provides water, $\mathrm{CO}_{2}$ that provides carbon, and particulate matter that provides a wide variety of nutrient sources and serves as substrate. Bacteria in the atmosphere, especially in aerosol particles, originate from soil, water, and plant surfaces (Jones and Harrison 2004) and once in the air, bacterial dispersion is carried out by air currents (wind speed and direction) (Olaya and Pérez 2005). 
Different studies have found a great bacterial diversity associated with particulate matter samples collected in the atmosphere near the surface, some of which are potential pathogens in animals, plants and humans that can have important effects on health (Bowers et al. 2011). They have identified different potentially pathogenic genera in the air, such as Acinetobacter, Bacillus, Corynebacterium, Kocuria, Mycobacterium, Micrococcus, Paenibacillus, Staphylococcus, Streptomyces, Enterobacter and Klebsiella (Griffin et al. 2007, Chen et al. 2012). The short-term effects of $\mathrm{PM}_{2.5}$ particulate matter exposure have shown that an increase in its concentration is associated with higher mortality rates, emergency room visits, increased respiratory symptoms and reduced lung function (Katsouyanni et al. 1997, von Klot et al. 2002, Pope and Dockery 2006). In recent years, several studies have noticed the presence of bacteria in the atmosphere (Després et al. 2007, Barahona 2010, Fahlgren et al. 2010), but Colombia has few air quality studies based on the microbiological component in urban or rural environments since they have been mainly focused on the physical and chemical characterization of the different air pollutants (Menetrez et al. 2007, Rave et al. 2008, Toro et al. 2010). Therefore, the present study aimed to evaluate the bacterial communities associated with $\mathrm{PM}_{2.5}$ particulate matter collected from two urban (Urban-C and Urban-NW) and one rural (Rural-N) locations from the Aburrá Valley, Colombia, South America.

\section{MATERIALS AND METHODS}

\section{Site description and sample collection}

This study was conducted in three locations from the Aburrá Valley, Antioquia, Colombia, South America. Sampling points in the urban area were selected based on traffic flow and population density: two sampling sites were located in the urban area of Medellín: Robledo neighborhood (Urban-C, $6^{\circ} 16^{\prime} 26.46$ "N; $\left.75^{\circ} 35^{\prime} 33.19^{\prime \prime} \mathrm{W}\right)$, located at the central-west part of the Aburrá Valley and Poblado neighborhood, located south of the Valley (UrbanNW, 6 $\left.{ }^{\circ} 12^{\prime} 32.06^{\prime \prime} \mathrm{N} ; 75^{\circ} 34^{\prime} 40.11^{\prime \prime} \mathrm{C}\right)$. A third sampling site was chosen, north of the Aburrá Valley, in the rural area of Barbosa, Antioquia (Rural-N, $6^{\circ} 24^{\prime} 23.24$ '”N; 75²5'9.08'W) (Fig. 1) (AMVA 2016).

For Urban-C site, samples were collected in both semesters of the year, from January to May (1st semester) and from July to December (2nd semester),
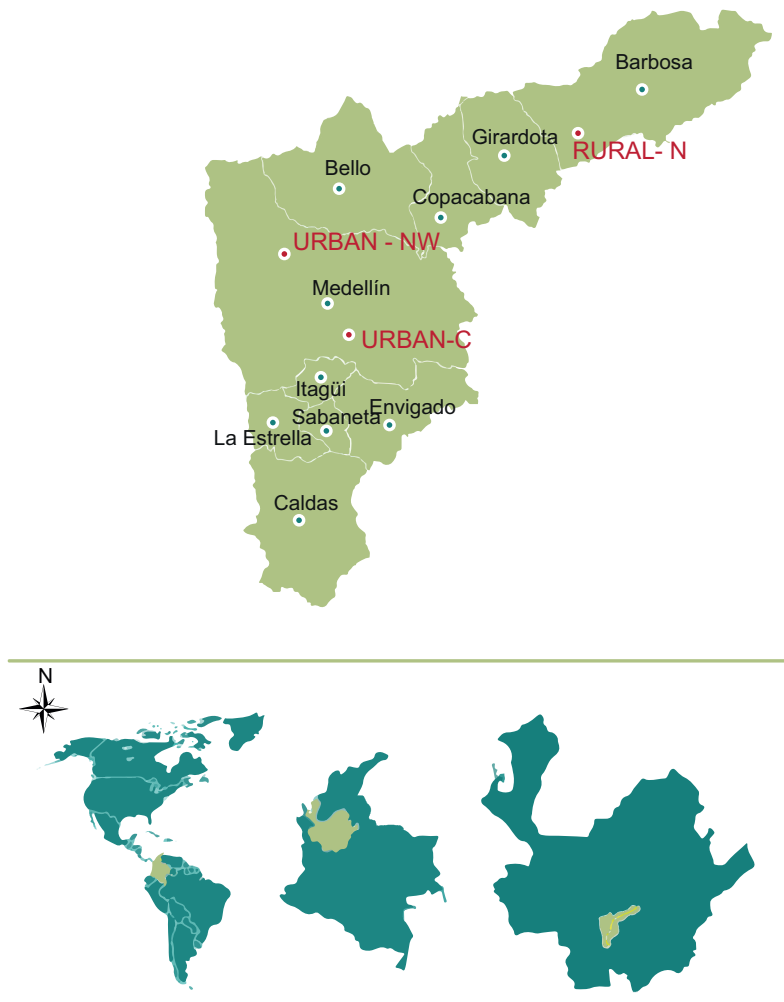

Fig. 1. Location of $\mathrm{PM}_{2.5}$ particulate matter sampling sites. Urban Area: Urban-C, 6 $6^{\circ} 16^{\prime} 26.46^{\prime \prime} \mathrm{N} ; 75^{\circ} 35^{\prime} 33.19^{\prime \prime} \mathrm{W}$ and Urban-NW, 6 ${ }^{\circ} 12^{\prime} 32.06^{\prime \prime} \mathrm{N} ; 7^{\circ} 34^{\prime} 40.11^{\prime \prime} \mathrm{C}$. Rural area: Rural-N, 6 24'23.24”N; 75'25'9.08'W. (Metropolitan Area of the Aburrá Valley, Antioquia, Colombia, South America). Scale: 1:10 km. Source: (AMVA 2016)

for a total of 20 samples processed. For Rural-N and Urban-NW, 14 filters were processed per site in the months of July and August. During these months, three simultaneous samplings were taken at all sampling points.

Samples were collected in polytetrafluoroethylene filters (PTFE, Ø $47 \mathrm{~mm}, 0.2 \mu \mathrm{m}$ pore size, Whatman) with low-volume air samplers: PQ200 semiautomatic (BGI Inc), Partisol 2000 (Thermo Electron Corp., MA, U.S.) and Partisol Plus 2025 (Thermo Electron Corp., MA, U.S.). The equipment absorbs the air at a constant volumetric flow rate of $16.7 \mathrm{~L} / \mathrm{m}$. The filter exposure time in was 24 hours (USEPA 1998, Menetrez et al. 2007).

\section{Environmental conditions}

Meteorological data such as air temperature, relative humidity and wind speed for each sampling site were taken using Vantage Pro 2 weather stations (Davis Instruments, Hayward, CA, USA). Canonical correspondence analysis (CCA) was implemented to 
establish a relationship between the species distribution matrix (presence/absence) and environmental conditions of the sampling sites (Legendre and Legendre 2012).

\section{Microbiological characterization}

To recover the bacteria from the $\mathrm{PM}_{2.5}$ particulate material, a half portion of the filter was mixed in brain heart infusion (BHI) enrichment broth (Merck) in order to release all the captured particles. It was then incubated at $37 \pm 2{ }^{\circ} \mathrm{C}$ for 24 hours and serially diluted $(1: 100000)$ to plate $0.1 \mathrm{~mL}$ per sample in chocolate agar (Merck), blood agar (Merck), eosine methylene blue (EMB) agar (Merck) and nutrient agar (Merck) (Legendre and Legendre 2012). Chocolate agar and blood agar were chosen as an enriched, bacterial growth medium for the isolation of fastidious organisms and certain opportunistic bacterial species that produce extracellular enzymes that lyse red blood cells in the blood agar (hemolysis). EMB agar is both a selective and differential culture medium for bacteria designed to selectively isolate Gram-negative and is commonly used for the isolation and differentiation of coliforms and fecal coliforms. Nutrient agar was chosen as a non-selective medium to promote growth of a diversity of microbes including nutritionally fastidious bacteria (Merck 2013).

Bacterial colonies obtained from the different culture media were sub-cultured in nutrient agar to obtain pure bacterial cultures and were characterized morphologically (size and shape of colony, elevation, pigmentation) and by Gram staining. In addition, hemolytic activity (alpha, beta or gamma) was determined on blood agar. For long-term preservation, all isolates were stored in liquid culture media with $20 \%$ glycerol and then frozen at $-20^{\circ} \mathrm{C}$ and $-80^{\circ} \mathrm{C}$.

\section{Molecular characterization}

Pure colonies were sub-cultured in nutrient agar at least three times and pure isolates were characterized by ribosomal intergenic spacer analysis (RISA) (Jensen et al. 1993, Moreno et al. 2002). RISA patterns were resolved by polyacrylamide gel electrophoresis (PAGE) and analyzed with GelCompar II software (Applied Biosystems Maths, Belgium) (García et al. 2016). RISA-PAGE was performed in a Mini-Protean Tetra cell electrophoresis unit with $7 \%$ polyacrylamide gels (acrylamide/bis-acrylamide 29:1) for $100 \mathrm{~min}$ at $130 \mathrm{~V}$. A clustering analysis by the Dice correlation method and the UPGMA similarity coefficient was elaborated (Nei and Li 1979, Mohammadi and Prasanna 2003).

A cluster was defined by isolates with $\geq 69 \%$ or more similarity percentage on their band patterns according to the dendrogram generated with GelCompar II software. From each cluster one or two isolates with different RISA patterns were identified through 16S rRNA gene sequencing using primers $27 \mathrm{~F}$ and $1492 \mathrm{R}$ (Table I).

\section{DNA sequence and phylogenetic analysis}

All amplification products were purified and sequenced on an ABI Prism 3100 Genetic Analyzer (Applied Biosystems, Carlsbad, CA, USA). Sequences were edited with ChromasPro 1.7.7 ® software (Technelysium) and the presence of chimeric sequences was evaluated with Decipher (Wright et al. 2012). The sequences obtained were compared with the GenBank database through Blast (Altschul et al. 1997) and the rRNA Database Project (RDP II) (Cole et al. 2009). Phylogenetic analyses were performed in Mega 6.1 software using the Neighbor-Joining method (Saitou and Nei 1987). The evolutionary distances were calculated using the Jukes-Cantor method and 1000 bootstrap replicates. (Tamura et al. 2007). All sequences were deposited in the NCBI database under accession numbers KY120748 to KY120773

\section{RESULTS AND DISCUSSION}

$\mathrm{PM}_{2.5}$ is a contaminant of interest in public health because it has the ability to penetrate the terminal bronchi and alveoli establishing an effective means

TABLE I. PRIMERS USED FOR 16S rDNA GENE AMPLIFICATION REACTIONS

\begin{tabular}{llcc}
\hline Primer & Sequence $\left(5^{\prime}-3^{\prime}\right)$ & Amplicon length & Reference \\
\hline 27F & AGAGTTTGATCMTGGCTCAG & 1500 & Moreno et al. 2002 \\
\cline { 1 - 2 } 1492R & TACGGYTACCTTGTTACGACTT & & \\
\hline L1 & CAAGGCATCCACCGT & $300-1000$ & Jensen et al. 1993 \\
\hline G1 & GAAGTCGTAACAAGG & & \\
\hline
\end{tabular}


of transport for pathogenic bacteria and opportunist microorganisms (Gil et al. 1997, Oyarzún 2010). PM$_{2.5}$ particulate matter regulation in Colombia tends to be permissive with respect to international values. For the country, the Ministerio de Ambiente, Vivienda y Desarrollo Territorial (Ministry of Environment, Housing and Territorial Development) (now the Ministerio de Ambiente y Desarrollo Sostenible -Ministry of Environment and Sustainable Development-) in 2010 established the daily and annual standards at $50 \mu \mathrm{g} / \mathrm{m}^{3}$ and $25 \mu \mathrm{g} / \mathrm{m}^{3}$ respectively while the World Health Organization (WHO) establishes far lower values (daily standard: $25 \mu \mathrm{g} / \mathrm{m}^{3}$ and annual standard: 10 $\mu \mathrm{g} / \mathrm{m}^{3}$ ). The short-term effects of $\mathrm{PM}_{2.5}$ particulate matter exposure have shown that an increase in its concentration is associated with higher mortality rates, emergency room visits, increased respiratory symptoms and reduced lung function (Katsouyanni et al. 1997, Von Klot et al. 2002, Pope and Dockery 2006)

In recent years, several studies have noticed the presence of bacteria in the atmosphere (Després et al. 2007, Barahona 2010, Fahlgren et al. 2010) but Colombia has few air quality studies based on the microbiological component in urban or rural environments since they have been mainly focused on the physical and chemical characterization of the different air pollutants (Menetrez et al. 2007, Rave et al. 2008, Toro et al. 2010). Therefore, the present study evaluated the bacterial communities associated with $\mathrm{PM}_{2.5}$ particulate matter collected from two urban (Urban-C and Urban-NW) and one rural (Rural-N) locations from the Aburrá Valley, Colombia, South America, using microbiological (agar plates, hemolytic activity) and molecular techniques (RISA and sequence analysis of the 16S rRNA gene).

\section{Influence of environmental conditions}

Meteorological and environmental factors play an important role in the release and distribution of pollutants and airborne microorganisms (Haas et al. 2013). Average concentration data measured in different sampling days presented higher amounts of $\mathrm{PM}_{2.5}$ for the Urban-C sampling site, followed by UrbanNW and Rural-N (Table II). This pattern is consistent with previous air quality studies which indicate that the $\mathrm{PM}_{2.5}$ concentration levels tend to be higher in densely populated urban areas with high traffic flow (Fang et al. 2007, Burrows et al. 2009, Wang et al. 2013). Likewise, the environmental conditions for each sampling site showed significant differences in wind speed, with the highest average values obtained for the Rural-N sampling site. The average temperature was similar for all sampling sites.

\section{Microbiological and molecular characterization}

Two hundred and sixteen (216) isolates were obtained from the different sampling sites. Sixtyfive percent $(65 \%)$ were beta hemolytic, indicating a high degree of pathogenicity in the recovered microorganisms since there is a total destruction of the beta hemoglobin (Table III). After morphological characterization (morphotypes, Gram stain) and hemolytic activity, 100 pure colonies were characterized by RISA. The banding pattern analysis of 100 isolates generated a dendrogram with 37 clusters, $>69 \%$ of which were similar (Supplement 1). One or two colonies were selected from each cluster with a total of fifty-seven isolates selected for 16S rDNA sequencing (Fig. 2). Twenty-six (26) different species were identified belonging to the phyla Firmicutes, Proteobacteria and

TABLE II. AVERAGES FOR PM ${ }_{2.5}$ PARTICULATE MATTER CONCENTRATION AND ENVIRONMENTAL CONDITIONS

\begin{tabular}{|c|c|c|c|c|c|c|c|c|c|}
\hline \multirow[t]{2}{*}{ Sampling site } & & \multicolumn{2}{|c|}{$\begin{array}{c}\text { Concentration } \\
\left(\mu \mathrm{g} / \mathrm{m}^{3}\right)\end{array}$} & \multicolumn{2}{|c|}{$\begin{array}{l}\text { Wind speed } \\
(\mathrm{m} / \mathrm{s})\end{array}$} & \multicolumn{2}{|c|}{$\begin{array}{c}\text { Temperature } \\
\left({ }^{\circ} \mathrm{C}\right)\end{array}$} & \multicolumn{2}{|c|}{$\begin{array}{c}\text { Relative } \\
\text { humidity }(\%)\end{array}$} \\
\hline & & $\bar{X}$ & $\sigma$ & $\bar{X}$ & $\sigma$ & $\bar{X}$ & $\sigma$ & $\bar{X}$ & $\sigma$ \\
\hline \multirow{2}{*}{ Urban-C* } & 1st semester & 23.21 & 2.4 & 0.41 & 0.2 & 22.44 & 1.8 & 62.81 & 2.7 \\
\hline & 2nd semester & 19.47 & 3.4 & 0.28 & 0.2 & 23.70 & 1.38 & 57.01 & 5.83 \\
\hline Urban-NW** & 2nd semester & 16.10 & 5.3 & 0.90 & 0.1 & 23.40 & 1.3 & 58.70 & 8.3 \\
\hline Rural-N** & 2nd semester & 11.50 & 2.4 & 1.50 & 0.3 & 22.60 & 0.8 & 72.10 & 4.9 \\
\hline
\end{tabular}

*Urban-C site, samples were collected from January to May (1st semester); and from July to December (2nd semester), for a total of 20 samples processed. **Urban-NW and Rural-N from July to August (2nd semester,) for 14 samples processed 
TABLE III. MICROBIOLOGICAL CHARACTERIZATION OF ISOLATES

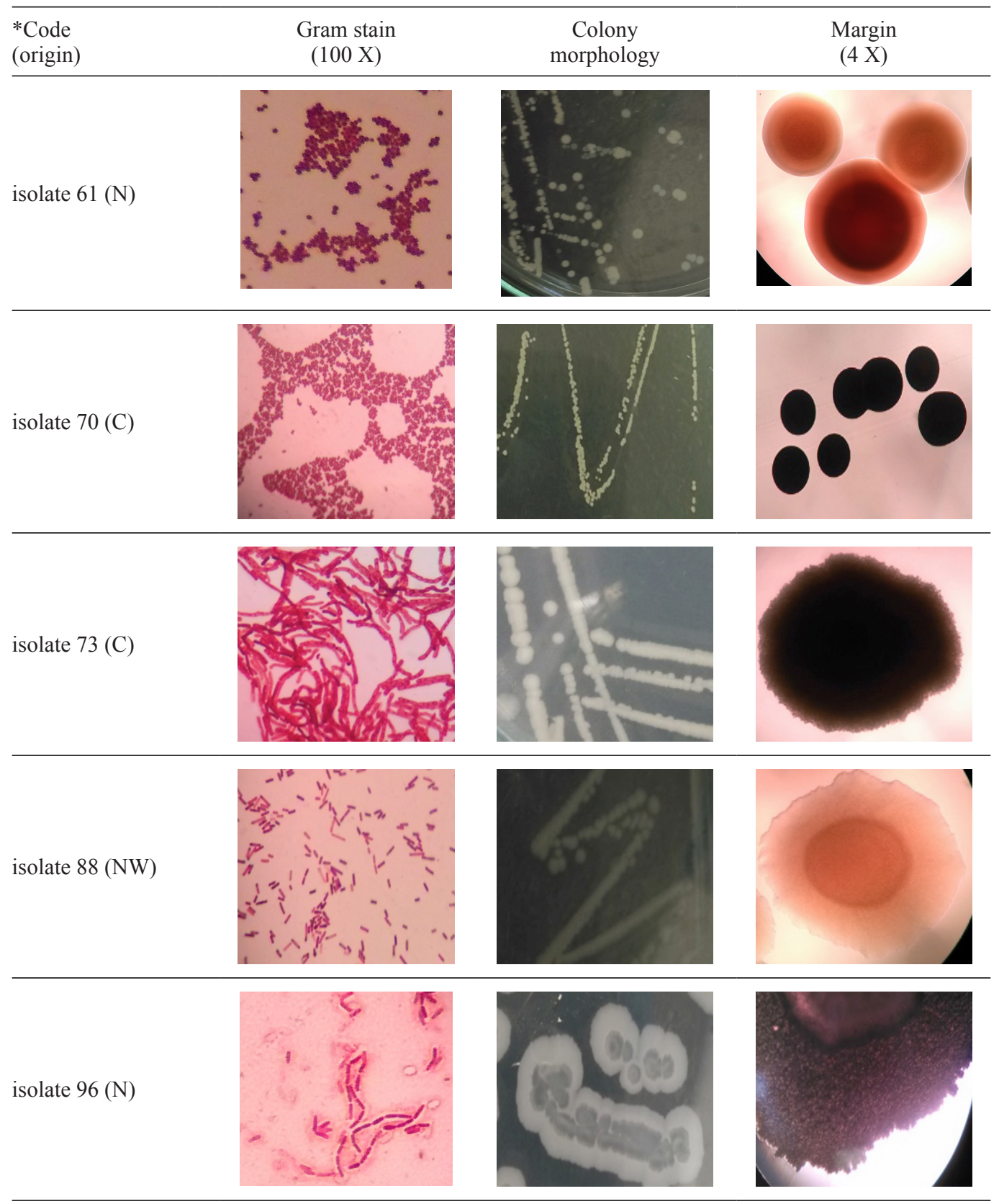

*Code $=$ isolate number and origin site Urban-C (C), Urban-NW (NW) and Rural-N (N)

Actinobacteria and all the sequences had high similarity (98-100\%) with sequences reported in the database (Table IV).

According to themolecularidentification(Table IV), phylum Firmicutes was the most abundant with genera like Bacillus, Staphylococcus, Paenibacillus, Lysinibacillus, Exiguobacterium and Macrococcus. These Gram positive genera are more resistant to dry or adverse conditions due to a thicker and peptidoglycan-rich cell wall, so they tend to be dominant in the culturable fraction of air samples (De La Rosa et al. 2002). They have also been reported in diverse locations such as forests, coasts, urban and rural areas.

Likewise, the genus Bacillus was the most abundant, possibly because of its ability to form endospores, a structure that allows them to remain 


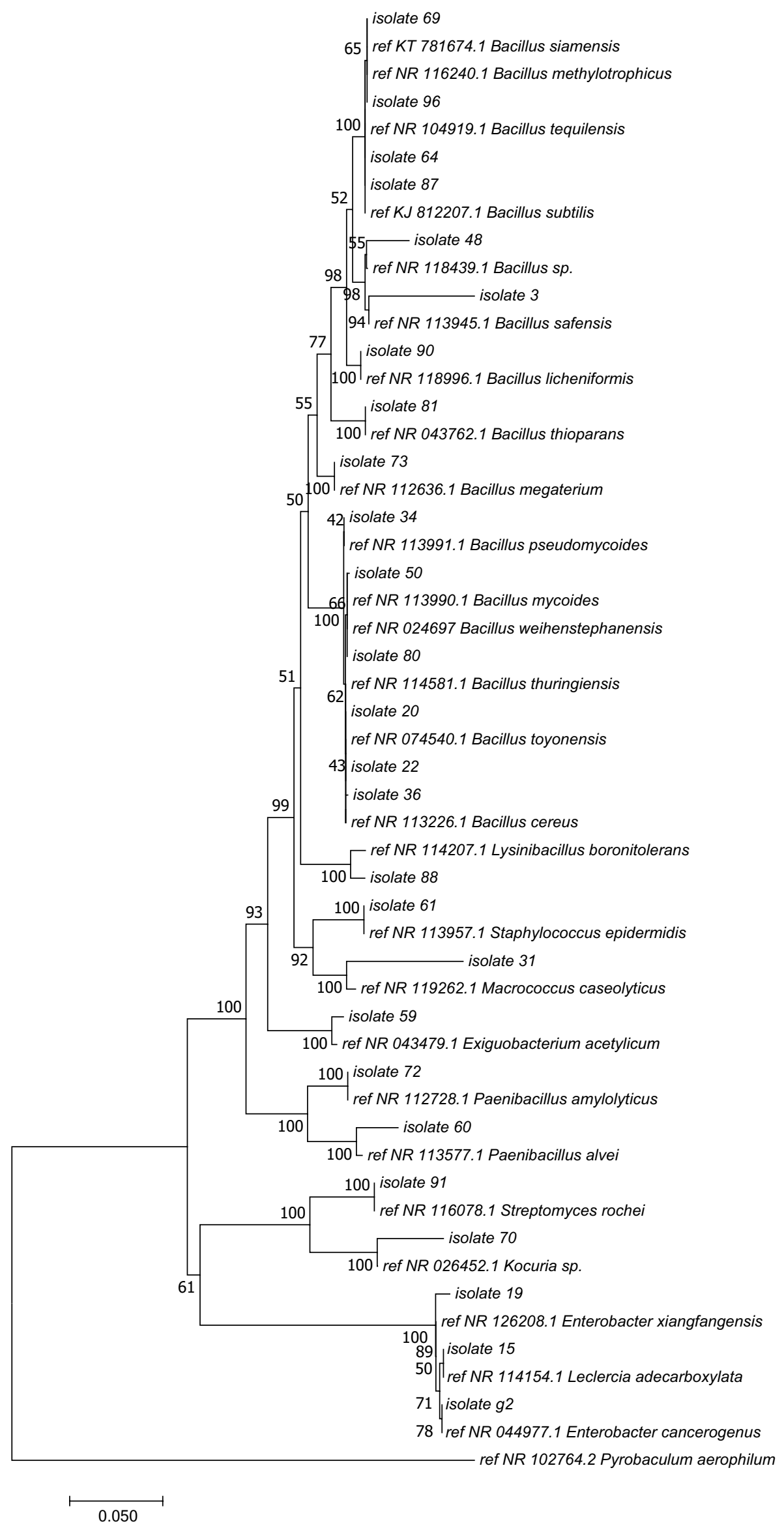

Fig. 2. Phylogenetic analysis based on 16S rRNA gene sequences of isolates from $\mathrm{PM}_{2.5}$ filters. The tree was produced by the NeighborJoining method with 1000 bootstrap repetitions, using Mega 6 software and a $16 \mathrm{~S}$ rRNA gene sequence from Pyrobaculum aerophilum as outgroup to improve the tree's topology 
TABLE IV. PHYLOGENETIC AFFILIATION OF MICROBIAL ISOLATES

\begin{tabular}{|c|c|c|c|}
\hline *Code (origin) & Accession \# & Phylogenetic affiliation & Closest relative accession \# (similarity \%) \\
\hline isolate $96(\mathrm{~N})$ & KY120764 & \multirow{21}{*}{ Firmicutes } & Bacillus methylotrophicus NR_116240.1 (99\%) \\
\hline isolate $60(\mathrm{NW})$ & KY120756 & & Paenibacillus alvei NR_113577.1 (97\%) \\
\hline isolate $61(\mathrm{~N})$ & KY120755 & & Staphylococcus epidermidis NR_113957.1 (99\%) \\
\hline isolate87 (C) & KY120750 & & Bacillus subtilis KJ_812207.1 (99\%) \\
\hline isolate $36(\mathrm{C})$ & KY120758 & & Bacillus cereus NR_113266.1 (99\%) \\
\hline isolate $90(\mathrm{C})$ & KY120749 & & Bacillus licheniformis NR_118996.1 (99\%) \\
\hline isolate $31(\mathrm{C})$ & KY120763 & & Macrococcus caseolyticus NR_119262.1 (99\%) \\
\hline isolate $88(\mathrm{NW})$ & KY120773 & & Lysinibacillus sp. NR_114207.1 (99%) \\
\hline isolate $48(\mathrm{C})$ & KY120760 & & Bacillus sp NR_118439.1 (96\%) \\
\hline isolate $22(\mathrm{NW})$ & KY120768 & & Bacillus toyonensis NR_074540.1 (99\%) \\
\hline isolate $34(\mathrm{C})$ & KY120761 & & Bacillus pseudomycoides NR_113991.1 (99\%) \\
\hline isolate $3(\mathrm{C})$ & KY120766 & & Bacillus safensis NR_113945.1 (99\%) \\
\hline isolate $64(\mathrm{C})$ & KY120771 & & Bacillus tequilensis $\overline{\mathrm{NR}} \_104919.1$ (99\%) \\
\hline isolate $20(\mathrm{C})$ & KY120759 & & Bacillus thuringiensis NR_114581.1 (99\%) \\
\hline isolate $81(\mathrm{~N})$ & KY120772 & & Bacillus thioparans NR_043762.1 (99\%) \\
\hline isolate $50(\mathrm{C})$ & KY120752 & & Bacillus mycoides NR_113990.1 (99 \%) \\
\hline isolate $73(\mathrm{C})$ & KY120753 & & Bacillus megaterium $\mathrm{NR} 112636.1$ (99\%) \\
\hline isolate $69(\mathrm{C})$ & KY120769 & & Bacillus siamensis KT_781674.1 (100\%) \\
\hline isolate $80(\mathrm{C})$ & KY120751 & & Bacillus weihenstephanensis NR_024697.1 (100\%) \\
\hline isolate $59(\mathrm{C})$ & KY120757 & & Exiguobacterium sp. NR_043479.1 (98\%) \\
\hline isolate $72(\mathrm{C})$ & KY120754 & & Paenibacillus amylolyticus NR_112728.1 (98 \%) \\
\hline isolate $2(\mathrm{C})$ & KY120767 & \multirow{3}{*}{ Proteobacteria } & Enterobacter cancerogenus NR_044977.1 (99\%) \\
\hline isolate $19(\mathrm{C})$ & KY120765 & & Enterobacter xiangfangensis NR_126208.1 (99\%) \\
\hline isolate $15(\mathrm{C})$ & KY120762 & & Leclercia adecarboxylata NR_114154.1 (99\%) \\
\hline isolate $70(\mathrm{C})$ & KY120770 & \multirow{2}{*}{ Actinobacteria } & Kocuria sp. NR_026452.1 (79\%) \\
\hline isolate $91(\mathrm{C})$ & KY120748 & & Streptomyces rochei NR_116078.1 (99\%) \\
\hline
\end{tabular}

${ }^{*}$ Code $=$ isolate number and origin site Urban-C (C), Urban-NW (NW) and Rural-N (N)

dormant for long periods of time under stress conditions, such as the environmental factors found in the atmosphere (Nicholson et al. 2000). Although the vast majority of Firmicutes are non-pathogenic bacteria, some species are well known pathogens such as $B$. cereus, $B$. licheniformis, $B$. thuringiensis, $B$. weihenstephanensis and $S$. epidermidis (Kotiranta et al. 2000, Murray et al. 2006, Thorsen et al. 2006) and some have been used for biotechnological applications as $B$. tequilensis and B. toyonensis (Jeong et al. 2012, Cortés-Camargo et al. 2016). S. epidermidis is part of the normal flora of the skin or mucous membranes of humans and is considered a ubiquitous bacterium in the air. It can remain viable for prolonged periods of time due to its resistance to desiccation and temperature changes. S. epidermidis is usually reported in indoor environments such as hospitals, residential buildings or offices (Bonetta et al. 2010). The appearance of $S$. epidermidis in all three monitoring points can be due to the proximity of the stations to educational and residential areas with considerable floating population. This could cause $S$. epidermidis to detach easily from the human body and contaminate the air, other people or inanimate environmental surfaces (Madsen et al. 2018).

Unlike Firmicutes, the phylum Proteobacteria is less resistant to desiccation and is usually present near marine environments where the relative humidity is high. This phylum has been found in air samples processed by culture-independent molecular techniques, as they can be difficult to recover from agar plates (Fahlgren et al. 2010). Something similar happened for the different sampling sites, where the implementation of EMB culture medium was intended for the isolation of rapidly developing Gram-negative bacteria and low nutritional requirements (Merck 2013), but the amount retrieved was quite small and observed only in the Urban-C sampling site. Gramnegative bacteria usually remain and survive in the air for very short periods of time (González 2006), due to its thin peptidoglycan layer (between $10 \%-20 \%$ ), this increases the susceptibility to mechanical rupture due to environmental factors such as the desiccation to which they are exposed in the environment and at 
the time of sampling (Tortora et al. 2007), the choice of recovery media and incubation conditions will also affect the survival of the bacteria. The identified isolates belonged to genera Enterobacter and Leclercia, members of the gamma-Proteobacteria group. These genera, usually found in soil, water, and vegetation, are members of the normal intestinal microbiota of many animals including humans and are common in clinical samples associated with polymicrobial infections (Murray et al. 2006, Correa et al. 2012). Some epidemiological studies in a rural zone of Colombia, show findings of faecal contamination in water probably by deficient sanitation and poor personal hygiene (Botero et al. 1984, Campos-Pinilla et al. 2008, Torres-Bejarano et al. 2018). The faecal contamination has not been reported as an important focus at the cities, however we cannot exclude the possibility that the generated excrement of dogs, cats, and even by humans on public roads can be transformed into dust and may pollute the air.

In the Urban-C sampling site, Actinobacteria from the Kocuria and Streptomyces genera were isolated and identified. This group of microorganisms has been detected mainly in urban environments and the vast majority are associated with land-based sources (Brodie et al. 2007, Hervàs et al. 2009, Fahlgren et al. 2010). Some species have been reported as causative agents of infections (Basaglia et al. 2002, Altuntas et al. 2004, Corti et al. 2012). For Streptomyces, some species are important as a source of secondary metabolites of high industrial value with antibacterial and antifungal applications (Ting et al. 2009, Jeffrey and Halizah 2014).

Additionally, in the Urban-C sampling site, the greatest diversity of bacterial isolates of the three sampling points was observed and as in the Urban-NW sampling site, they had the highest amount of bacteria with potentially harmful effects on human health like B. cereus (Murray et al. 2006), Staphylococcus epidermidis (Murray et al. 2006), Leclercia adecarboxylata (Correa et al. 2012) and B. licheniformis (Veith et al. 2004). These results raise concern since these sampling sites are directly influenced by high traffic flow and are near large educational and residential sectors.

However, in the Rural-N sampling site where green areas predominate and $\mathrm{PM}_{2.5}$ pollution problems are not as severe as in urban areas, most of the identified microorganisms belonged to $B$. subtilis, B. thioparans, B. safensis and B. methylotrophicus species (Deepa et al. 2010, Yu et al. 2011, Dias et al. 2015), and have been associated as potential agents for biological control of plant diseases or as growth promoters.

\section{Correlation between the bacterial diversity pres- ent in the $\mathbf{P M}_{2.5}$ particulate material and the geo- graphical location of the sampling sites}

The canonical correspondence analysis for simultaneous samplings at the three sampling sites carried out in the months of July and August 2015 (Fig. 3), displays that the bacterial diversity between both sampling sites located in urban areas at

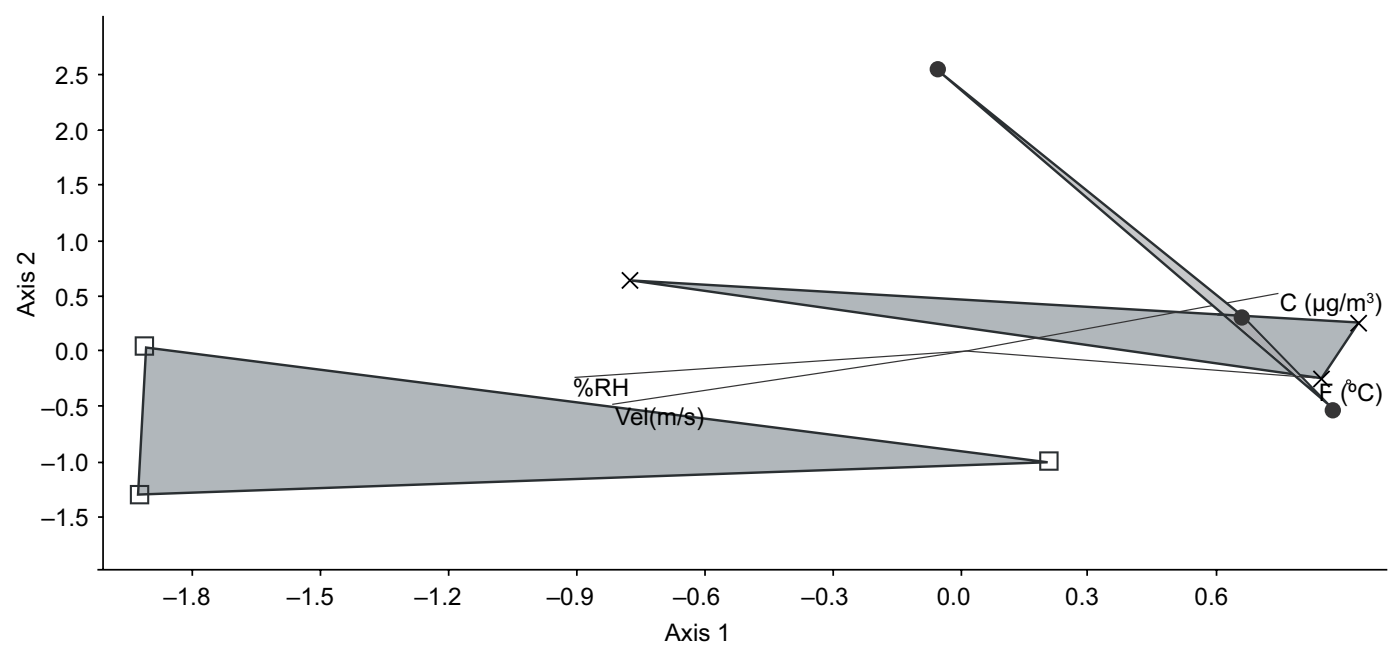

Fig. 3. Canonical correspondence analysis from the presence/absence matrix of bacterial isolates and environmental conditions of three simultaneous samplings: Urban-C = Robledo neighbourhood $(\bullet)$, Urban-NW $=$ Poblado neighbourhood $(\times)$, Rural-N $=$ rural area of Barbosa $(\square), \mathrm{T}:=$ temperature, $\mathrm{C}=$ concentration of $\mathrm{PM}_{2.5}, \% \mathrm{RH}=$ Relative Humidity, $\mathrm{Vel}=$ wind speed. 
the Aburrá Valley (Urban-C and Urban-NW), were similar. The sampling site located in the rural area (Rural-N) presented bacterial species observed in the urban sampling sites such as $B$. licheniformis, B. methylotrophicus, B. subtilis and S. epidermidis and in addition to these, unique bacteria for this sampling site were also observed such as $B$. thioparans, $M$. boronitolerans and L. caseolyticus. These differences are probably the result of weather changes, combined with anthropogenic influences like changes in land use and concentration of particulate matter, which can alter the atmospheric microbial composition (Fahlgren et al. 2010).

This shows that there is a greater presence of opportunistic pathogenic microorganisms in urban areas compared with the sampling site located in a rural area and can probably explain why there is a greater level of contamination in the Urban-C and Urban-NW sampling sites. Although high levels of particulate matter $\mathrm{PM}_{2.5}$ have been clearly linked to adverse health effects, it is speculated that the similarity of airborne bacteria may be caused by anthropogenic activities, including pollution, industrial activity, fuels and fires (Wang et al. 2013, AMVA 2017). $\mathrm{PM}_{2.5}$ does not sediment in short periods but remains suspended in the air due to its size and density (Ginzburg et al. 2015). The level of human exposure depends on the pollutant emission rate of vehicles, the direction of transport, the dispersion rate and the location of the population in relation to the set of mobile sources (Baldauf et al. 2018). Likewise, the presence of pathogenic or opportunistic bacteria associated with this contaminant indicates that there may be a higher risk of disease in people, but the individual reactions to these pollutants depend largely on factors such as health, genetic load and the degree of exposure of people (Sun et al. 2010). Reducing the pollutant emission at origin, toxic emissions from industrial sources and better municipal management would prevent and reduce air pollution.

In summary, this research comprises an initial investigation for the study of bioaerosols present in $\mathrm{PM}_{2.5}$ particles in Colombia. These bioaerosols are a cause for concern because of their potential impact on occupational health as well as on the health of people living near or are continuously exposed to them. Airborne bacteria are clearly an important, but understudied, component of air quality that needs to be better integrated into efforts to measure and model the particles pollutants in the atmosphere and correlate the results with epidemiological information and contaminant dispersion.

\section{CONCLUSIONS}

The detection of bacteria associated with particulate matter $\mathrm{PM}_{2.5}$ highlights the relevance of bioaerosols studies and is useful as an indicator of air pollution that had not been taken into account before in Colombia. Results suggest that the presence of specific bacteria can be influenced by particulate matter and environmental factors.

\section{ACKNOWLEDGMENTS}

This research was financed by the Universidad Nacional de Colombia (National University of Colombia) (Project 30372) and the environmental authority of the Metropolitan Area of the Aburrá Valley, (Inter-administrative Agreement No. 326 of 2014).

\section{REFERENCES}

Altschul S. F., Madden T. L., Schäffer A. A., Zhang J., Zhang Z., Miller W. and Lipman D. J. (1997). Gapped BLAST and PS I-BLAST: A new generation of protein database search programs. Nucleic Acids Res. 25 (17), 3389-3402.

DOI: $10.1093 / \operatorname{nar} / 25.17 .3389$

Altuntas F., Yildiz O., Eser B., Gündogan K., Sumerkan B. and Çetin M. (2004). Catheter-related bacteremia due to Kocuria rosea in a patient undergoing peripheral blood stem cell transplantation. BMC Infe. Dis. 4 (1), 62. DOI: 10.1186/1471-2334-4-62

AMVA (2016). Experiencia del área metropolitana del Valle de Aburrá: hacia la integracion regional sostenible. Área metropolitana del Valle de Aburrá [online]. https://www.metropol.gov.co/ 06/07/2016.

AMVA (2017). Acuerdo metropolitano No. 16. Plan integral de gestión de contaminación del airePIGECA. Área metropolitana del Valle de Aburrá. 6/12/2017.

Baldauf R., Thoma E., Hays, M., Shores R., Kinsey J., Gullett B., Kimbrough S., Isakov V., Long T., Snow R., Khlystov A., Weinstein J., Chen F.L., Seila R., Olson D., Gilmour I., Cho S.H., Watkins N., Rowley P. and Bang J. (2008). Traffic and meteorological impacts on near-road air quality: summary of methods and trends from the raleigh near-road study. J. Air Waste Manag. Assoc. 58 (7), 865-878.

DOI: $10.3155 / 1047-3289.58 .7 .865$

Barahona S. (2010). Microbiological study of SantiagoChile atmospheric particulate material through 
molecular biology tools. M.Sc. Thesis. Facultad de Ciencias Forestales y Conservación de la Naturaleza, Universidad de Chile. Santiago, Chile, 74 pp.

Basaglia G., Carretto E., Barbarini D., Moras L., Scalone S., Marone P. and De Paoli P. (2002). Catheter-related bacteremia due to Kocuria kristinae in a patient with ovarian cancer. J. Clin. Microbiol. 40 (1), 311-313. DOI: 10.1128/JCM.40.1.311-313.2002

Bedoya J. and Martínez E. (2009). Quality of the air in the Valley of Aburrá. Antioquia Colombia. Revista Dyna 76 (158), 7-15.

Blanco L. (2003). Caracterización microbiológica del material particulado como factor de riesgo sobre la salud en la localidad de Puente Aranda. Proceedings. VI Seminario internacional del medio ambiente y desarrollo sostenible dentro del simposio salud y ambiente. Bogotá, Colombia. October 2003, 1-9 pp.

Bonetta S., Bonetta S., Mosso S., Sampo S. and Carraro E. (2010). Assessment of microbiological indoor air quality in an Italian office building equipped with an HVAC system. Environ. Monit. Assess. 161, 473-483. DOI: 10.1007/s10661-009-0761-8

Botero C. A., Cálad G. A., Cardona E. A., Correa D. H. and González C. M. (1984). Epidemiologia de las helmintiasis intestinales en una zona rural de Antioquia, Colombia. (Control por tratamiento comunitario). Medicina UPB 3 (1), 66-78.

Bowers R., Lauber C., Wiedinmyer C., Hamady M., Hallar A., Fall R., Knight R. and Fierer N. (2009). Characterization of airborne microbial communities at a high-elevation site and their potential to act as atmospheric ice nuclei. Appl. Environ. Microb. 75 (15), 5121-5130.

DOI: 10.1128/AEM.00447-09

Bowers R., Sullivan A., Costello E., Collett J., Knight R. and Fierer N. (2011). Sources of bacteria in outdoor air across cities in the midwestern United States. Appl. Environ. Microb. 77 (18), 6350-6356.

DOI: 10.1128/AEM.05498-11

Brodie E. L., DeSantis T. Z., Parker J. P. M., Zubietta I. X., Piceno Y. M. and Andersen G. L. (2007). Urban aerosols harbor diverse and dynamic bacterial populations. P. Natl. Acad. Sci. USA. 104 (1), 299-304.

DOI: $10.1073 /$ pnas.0608255104

Burrows S., Elbert W., Lawrence M. and Pöschl U. (2009). Bacteria in the global atmosphere - part 1: review and synthesis of literature data for different ecosystems. Atmos. Chem. Phys. 9 (3), 10777-10827. DOI: 10.5194/acpd-9-10777-2009

Campos-Pinilla C., Cárdenas-Guzmán M. and GuerreroCañizares A. (2008). Performance of faecal contamination indicators in different type of waters from the sabana of Bogotá (Colombia). Univ. Sci. 13 (2), 103-108.
Chen X., Ran P., Ho K., Lu W., Li B., Gu Z., Song C. and Wang J. (2012). Concentrations and size distributions of airborne microorganisms in Guangzhou during summer. Aerosol Air Qual. Res. 12 (6), 1336-1344. DOI: 10.4209/aaqr.2012.03.0066

Cole J. R., Wang Q., Cardenas E., Fish J., Chai B., Farris R. J. and Garrity G. M. (2009). The ribosomal database project: improved alignments and new tools for rRNA analysis, Nucleic Acids Res. 37 (suppl 1), D141-D145. DOI: http://doi.org/10.1093/nar/gkn879

Correa A., Mazo L., Valderrama M., Restrepo A. and Jaimes F. (2012). An outbreak of Leclercia adecarboxylata bacteremia likely associated to contaminated heparin vials. Infect. 16 (2), 117-121.

DOI: $10.1016 / \mathrm{S} 0123-9392(12) 70065-6$

Cortés-Camargo S., Pérez-rodríguez N., Pinheiro R., Oliveira D., Barragán B. and Manuel J. (2016). Production of biosurfactants from vine-trimming shoots using the halotolerant strain Bacillus tequilensis ZSB10. Ind. Crop. Prod. 79, 258-266.

DOI: $10.1016 /$ j.indcrop.2015.11.003

Corti M., Villafañe M., Soto I., Palmieri O. and Callejo R. (2012). Bacteremia by Kocuria rosea in a patient with SIDA. Rev. Chil. Infectol. 29 (3), 1344-1346. DOI: $10.4067 / \mathrm{S} 0716-10182012000300019$

De La Rosa M., Mosso M. and Ullán C. (2002). Air: habitat and means of transmission of microorganisms. Observatorio Medioambiental 5, 375-402. [online] http:// dialnet.unirioja.es/servlet/articulo? codigo $=2147812$ 10/02/2018.

Deepa C., Dastager S. and Pandey A. (2010). Plant growthpromoting activity in newly isolated Bacillus thioparus (NII-0902) from western ghat forest, India. World J. Microb. Biot. 26 (12), 2277-2283.

DOI: $10.1007 / \mathrm{s} 11274-010-0418-3$

Després V., Nowoisky J., Klose M., Conrad R., Andreae M. and Pöschl U. (2007). Molecular genetics and diversity of primary biogenic aerosol particles in urban, rural, and high-alpine air. Biogeosci. Discuss. 4 (1), 349-384.

Dias L., Caetano T., Pinheiro M. and Mendo S. (2015). The lanthipeptides of Bacillus methylotrophicus and their association with genomic islands. Syst. Appl. Microbiol. 38 (8), 525-533. DOI: $10.1016 /$ j.syapm.2015.10.002

Fahlgren C., Hagstrom A., Nilsson D. and Zweifel U. (2010). Annual variations in the diversity, viability, and origin of airborne bacteria. Appl. Environ. Microb. 76 (9), 3015-3025. DOI: 10.1128/AEM.02092-09

Fang Z., Ouyang Z., Zheng H., Wang X. and Hu L. (2007). Culturable airborne bacteria in outdoor environments in Beijing, China. Microb. Ecol. 54 (3), 487-496. DOI: $10.1007 / \mathrm{s} 00248-007-9216-3$ 
Focil R., Cid A. and Rosique E. (1999). AEROBIOLOGY: The science of airborne microorganisms and their environment. Revista de Divulgación 5 (9), 62-68.

García G., M., Márquez G., M. A. and Moreno H. C. X. (2016). Characterization of bacterial diversity associated with calcareous deposits and drip-waters, and isolation of calcifying bacteria from two Colombian mines. Microbiol. Res. 182, 21-30.

DOI: $10.1016 /$ j.micres.2015.09.006

Gaviria C., Benavides P. and Tangarife C. (2011). Pollution by particulate matter $\left(\mathrm{PM}_{2.5}\right.$ and $\left.\mathrm{PM}_{10}\right)$ and consultations for respiratory diseases in Medellín (2008-2009). Rev. Fac. Nac. Salud Pública, 29 (3), 241-250.

Gil L., Cáceres D., Quiñones L. and Adonis M. (1997). Contaminación del aire en espacios interiores y exteriores en la ciudad de Temuco. Ambiente y Desarrollo 13 (1), 70-78.

Ginzburg H., Liu X., Baker M., Shreeve R., Jayanty R. K. M., Campbell D. and Zielinska B. (2015). Monitoring study of the near-road $\mathrm{PM}_{2.5}$ concentrations in Maryland. J. Air. Waste Manage. 65 (9), 1062-1071. DOI: 10.1080/10962247.2015.1056887

González B. A. X. (2006). Calidad bacteriológica en el aire del centro histórico de la ciudad de Guadalajara. Jalisco, México. M.Sc. Thesis. Centro Universitario de Ciencias Biológicas y Agropecuarias, Universidad de Guadalajara. Guadalajara, México, 92 pp.

Griffin D. W., Kubilay N., Koçak M., Gray M. a., Borden T. C. and Shinn E. (2007). Airborne desert dust and aeromicrobiology over the Turkish mediterranean coastline. Atmos. Environ. 41 (19), 4050-4062.

DOI: 10.1016/j.atmosenv.2007.01.023

Haas D., Galler H., Luxner J., Zarfel G., Buzina W., Friedl H. and Reinthaler F. F. (2013). The concentrations of culturable microorganisms in relation to particulate matter in urban air. Atmos. Environ. 65, 215-222. DOI: 10.1016/j.atmosenv.2012.10.031

Hervàs A., Camarero L., Reche I. and Casamayor E. (2009). Viability and potential for immigration of airborne bacteria from Africa that reach high mountain lakes in Europe. Environ. Microbiol. 11 (6), 1612-1623.

DOI: $10.1111 / \mathrm{j} .1462-2920.2009 .01926 . x$

Jeffrey L. and Halizah H. (2014). Impact of media composition and growth condition of antifungal production by Streptomyces ambofaciens S2. Afr. J. Microbiol. Res. 8 (10), 994-1000.

DOI: $10.5897 / A J M R 11.140$

Jensen M., Webster J. and Straus N. (1993). Method for rapid identification of bacteria based on Polymerase Chain-Reaction amplified ribosomal DNA spacer polymorphisms. Appl. Environ. Microb. 59 (4), 945-952.
Jeong H., Jeong D. E., Kim S. H., Song G. C., Park S. Y., Ryu C. M. and Choi S. K. (2012). Draft genome sequence of the plant growth-promoting bacterium Bacillus siamensis KCTC 13613T. J. Bacteriol. 194 (15), 4148-4149. DOI: 10.1128/JB.00805-12

Jones A. M. and Harrison R. M. (2004). The effects of meteorological factors on atmospheric bioaerosol concentrations - A review. Sci. Total Environ. 326 (1-3), 151-180. DOI: 10.1016/j.scitotenv.2003.11.021

Katsouyanni K., Touloumi G., Spix C., Schwartz J., Balducci F., Medina S. and Anderson H. R. (1997). Short-term effects of ambient sulphur dioxide and particulate matter on mortality in 12 European cities: results from time series data from the APHEA project. Air Pollution and Health: a European Approach. Brit. Med. J. 314 (7095), 1658-1663.

DOI: $10.1136 / \mathrm{bmj} .314 .7095 .1658$

Kotiranta A., Lounatmaa K. and Haapasalo M. (2000). Epidemiology and pathogenesis of Bacillus cereus infections. Microbes Infect. 2 (2), 189-198.

DOI: $10.1016 / \mathrm{S} 1286-4579(00) 00269-0$

Lee B. U., Yun S. H., Ji J. H. and Bae G. N. (2008). Inactivation of $S$. epidermidis, B. subtilis, and E. coli bacteria bioaerosols deposited on a filter utilizing airborne silver nanoparticles. J. Microbiol. Biotechn. 18 (1), 176-182.

Legendre P. and Legendre L. (2012). Numerical ecology. Developments in environmental modeling. 3rd ed. Elsevier. Amsterdam, The Netherlands, 989 pp.

Madsen A. M., Moslehi-Jenabian S., Islam M. Z., Frankel M., Spilak M. and Frederiksen M. W. (2018). Concentrations of Staphylococcus species in indoor air as associated with other bacteria, season, relative humidity, air change rate, and S. aureus - positive occupants. Environ. Res. 160, 282-291.

DOI: $10.1016 /$ j.envres.2017.10.001

Menetrez M. Y., Foarde K. K., Esch R. K., Dean T. R., Betancourt D. A., Moore S. A., Svendsen E. R. and Yeatts K. (2007). The measurement of ambient bioaerosol exposure. Aerosol Sci. Tech. 41 (9), 884-893. DOI: $10.1080 / 02786820701523083$

Merck (2013). Microbiology manual. 12th ed. Merck Publications, Darmstadt, Germany, 689 pp.

Miller K., Siscovick D., Sheppard L., Shepherd K., Sullivan J., Anderson G. and Kaufman J. (2007). Long-term exposure to air pollution and incidence of cardiovascular events in women. New Engl. J. Med. 356 (5), 447-458.

DOI: 10.1056/NEJMoa054409

Mohammadi S. and Prasanna B. (2003). Analysis of genetic diversity in crop plants-salient statistical tools and considerations. Crop. Sci. 43 (4), 1235-1248.

DOI: $10.2135 /$ cropsci2003.1235 
Moreno C., Gómez E., Pérez O., Romero M. and Cadavid G. (2010). Antimicrobial activity of bacteria associated with the spiral snail (Strombus gigas) of the Colombian caribbean coast. Revista Cuadernos Del Caribe 8 (14), 125-135.

Moreno C., Romero J. and Espejo R. (2002). Polymorphism in repeated 16S rRNA genes is a common property of type strains and environmental isolates of the genus Vibrio. Microbiology 148 (4), 1233-1239. DOI: 10.1099/00221287-148-4-1233

Murray P., Rosenthal K. and Pfaller M. (2006). Microbiología médica. 6ta ed. Elsevier, Barcelona, Spain, 894 pp.

Nei M. and Li W. H. (1979). Mathematical model for studying genetic variation in terms of restriction endonucleases. P. Natl. Acad. Sci. USA. 76 (10), 5269-5273.

DOI: $10.1073 /$ pnas.76.10.5269

Nicholson W., Munakata N., Horneck G., Melosh H. and Setlow P. (2000). Resistance of Bacillus endospores to extreme terrestrial and extraterrestrial environments. Microbiol Mol. Biol. R. 64 (3), 548-572.

DOI: 10.1128/MMBR.64.3.548-572.2000

O’Neill M. S., Jerrett M., Kawachi I., Levy J. I., Cohen A. J., Gouveia N. and Zanobetti A. (2003). Health, wealth, and air pollution: advancing theory and methods. Environ. Health Persp. 111 (16), 1861-1870.

DOI: $10.1289 /$ ehp.6334

Olaya D. and Pérez F. (2005). Qualitative-quantitative characterization of bioaerosols related to meteorological factors and particulate matter in Puente Aranda, Bogotá D.C, Colombia. Tesis de Pregrado. Facultad de Ingeniería Ambiental y Sanitaria, Universidad de la Salle. Bogotá, Colombia, 201 pp.

Oyarzún G. (2010). Air pollution and its effects on health. Rev. Chil. Enferm. Respir. 26 (1), 16-25.

DOI: $10.4067 / \mathrm{S} 0717-73482010000100004$

Pope C. A. and Dockery D. W. (2006). Health effects of fine particulate air pollution: lines that connect. J. Air Waste Manage. 56 (6), 709-742.

DOI: $10.1080 / 10473289.2006 .10464485$

Rave C., Builes L., Ossa J. and Smith R. (2008). Identification of critical areas for air pollution in the metropolitan area of the Valley of Aburrá, for support in the decision making of environmental and territorial ordering. Investigación en Gestión y Ambiente 11 (1), 55-66.

Saitou N. and Nei M. (1987). The Neighbor-joining method: A new method for reconstructing phylogenetic trees. Mol. Biol. Evol. 4 (4), 406-425.

DOI: 10.1093/oxfordjournals.molbev.a040454

Sun Q., Hong X. and Wold L. (2010). Cardiovascular effects of ambient particulate air pollution exposure.
Circulation 121 (25), 2755-2765.

DOI: 10.1161/CIRCULATIONAHA.109.893461

Tamura K., Dudley J., Nei M. and Kumar S. (2007). MEGA4: Molecular evolutionary genetics analysis (MEGA) software version 4.0. Mol. Biol. Evol. 24 (8), 1596-1599. DOI: $10.1093 / \mathrm{molbev} / \mathrm{msm} 092$

Thorsen L., Hansen B., Nielsen K., Hendriksen N., Phipps R. and Budde B. (2006). Characterization of emetic Bacillus weihenstephanensis, a new cereulideproducing bacterium. Appl. Environ. Microb. 72 (7), 5118-5121.

DOI: 10.1128/AEM.00170-06

Ting S., Tan S. and Wai M. (2009). Isolation and characterization of Actinobacteria with antibacterial activity from soil and rhizosphere soil. Australian Journal of Basic and Applied Sciences 3 (4), 4053-4059.

Torres-Bejarano F., González-Márquez L. C., Díaz-Solano B., Torregroza-Espinosa A. C. and Cantero-Rodelo R. (2018). Effects of beach tourists on bathing water and sand quality at Puerto Velero, Colombia. Environ. Dev. Sustain. 20 (1), 255-269. DOI: $10.1007 / \mathrm{s} 10668-016-9880-\mathrm{x}$

Toro V., Molina E., Patiño J., Fernandez M. and Ramirez G. (2010). Plan decontamination of the air in the metropolitan region of the Valley of Aburrá. Producción + Limpia. 5 (1), 10-26.

Tortora G., Funke B. and Case C. (2007). Introducción a la microbiología. 9na ed. Editorial Médica Panamericana, Buenos Aires, Argentina, 963 pp.

USEPA (1998). $\mathrm{PM}_{2.5}$ mass weighing laboratory standard operating procedures for the performance evaluation program. United States Environmental Protection Agency. Method Compendium, Washington, D.C., EUA, $165 \mathrm{pp}$.

Veith B., Herzberg C., Steckel S., Feesche J., Maurer K., Ehrenreich P. and Gottschalk G. (2004). The complete genome sequence of Bacillus licheniformis DSM13, an organism with great industrial potential. J. Mol. Microb. Biotech. 7 (4), 204-211.

DOI: $10.1159 / 000079829$

Von Klot S., Wölke G., Tuch T., Heinrich J., Dockery D. W., Schwartz J. and Peters A. (2002). Increased asthma medication use in association with ambient fine and ultrafine particles. Eur. Respir. J. 20 (3), 691-702.

DOI: $10.1183 / 09031936.02 .01402001$

Wang G. H., Zhou B. H., Cheng C. L., Cao J. J., Li J. J., Meng J. J. and Fu P. Q. (2013). Impact of Gobi Desert dust on aerosol chemistry of Xi' an, inland China during spring 2009: differences in composition and size distribution between the urban ground surface and the mountain atmosphere. Atmos. Chem. Phys. 13 (2), 819-835. DOI: 10.5194/acp-13-819-2013. 
WHO (2005). WHO air quality guidelines for particulate matter, ozone, nitrogen dioxide and sulfur dioxide. World Health Organization. Global update 2005, Geneva, Switzerland, 22 pp.

Wright E. S., Yilmaz L. S. and Noguera D. (2012). DECIPHER, a search-based approach to chimera identification for $16 \mathrm{~S}$ rRNA sequences. Appl. Environ. Microb. 78, 717-725. DOI: 10.1128/AEM.06516-11
Yu X., Ai C., Xin L. and Zhou G. (2011). The siderophoreproducing bacterium, Bacillus subtilis CAS15, has a biocontrol effect on Fusarium wilt and promotes the growth of pepper. Eur. J. Soil Biol. 47 (2), 138-145. DOI: 10.1016/j.ejsobi.2010.11.001 


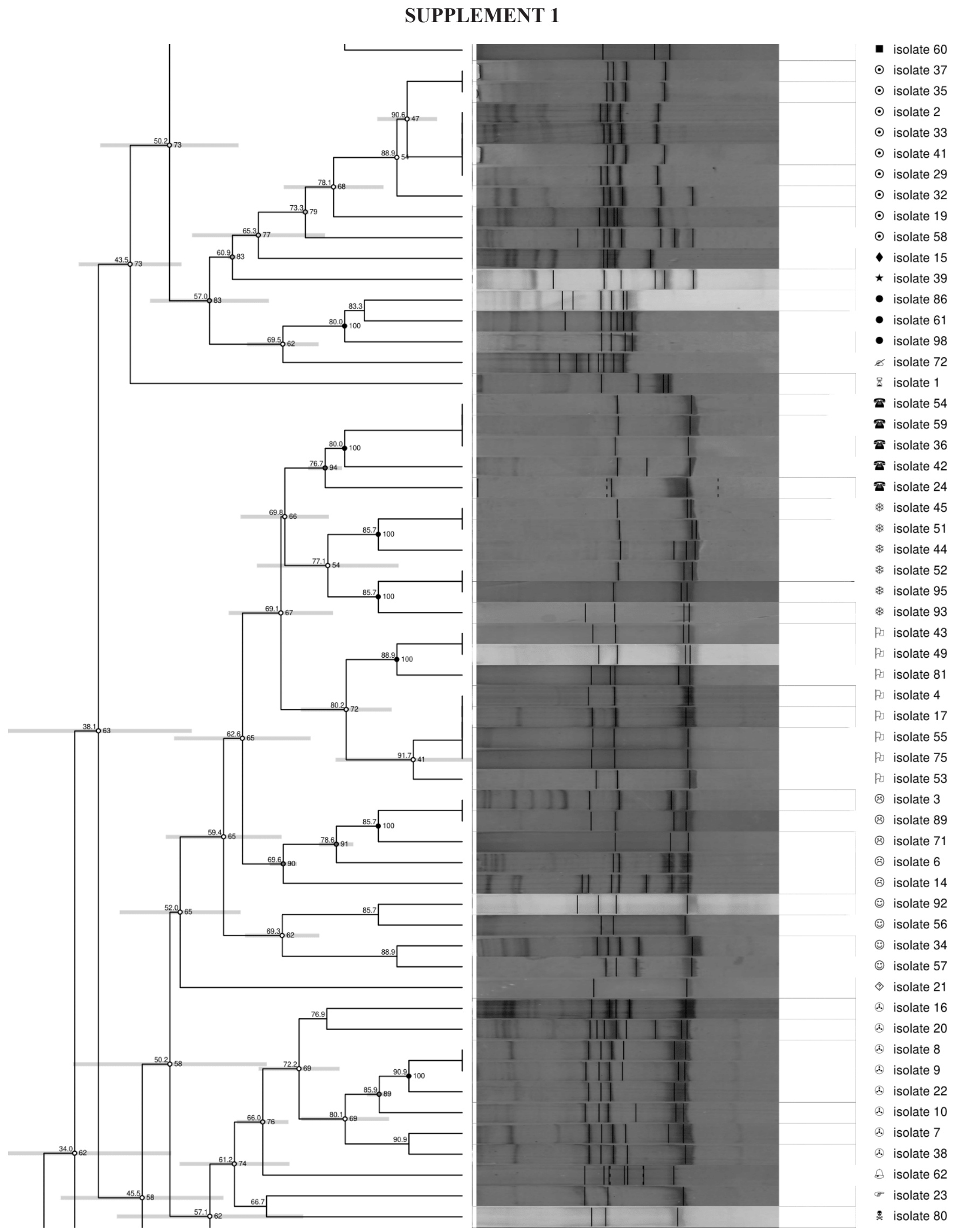



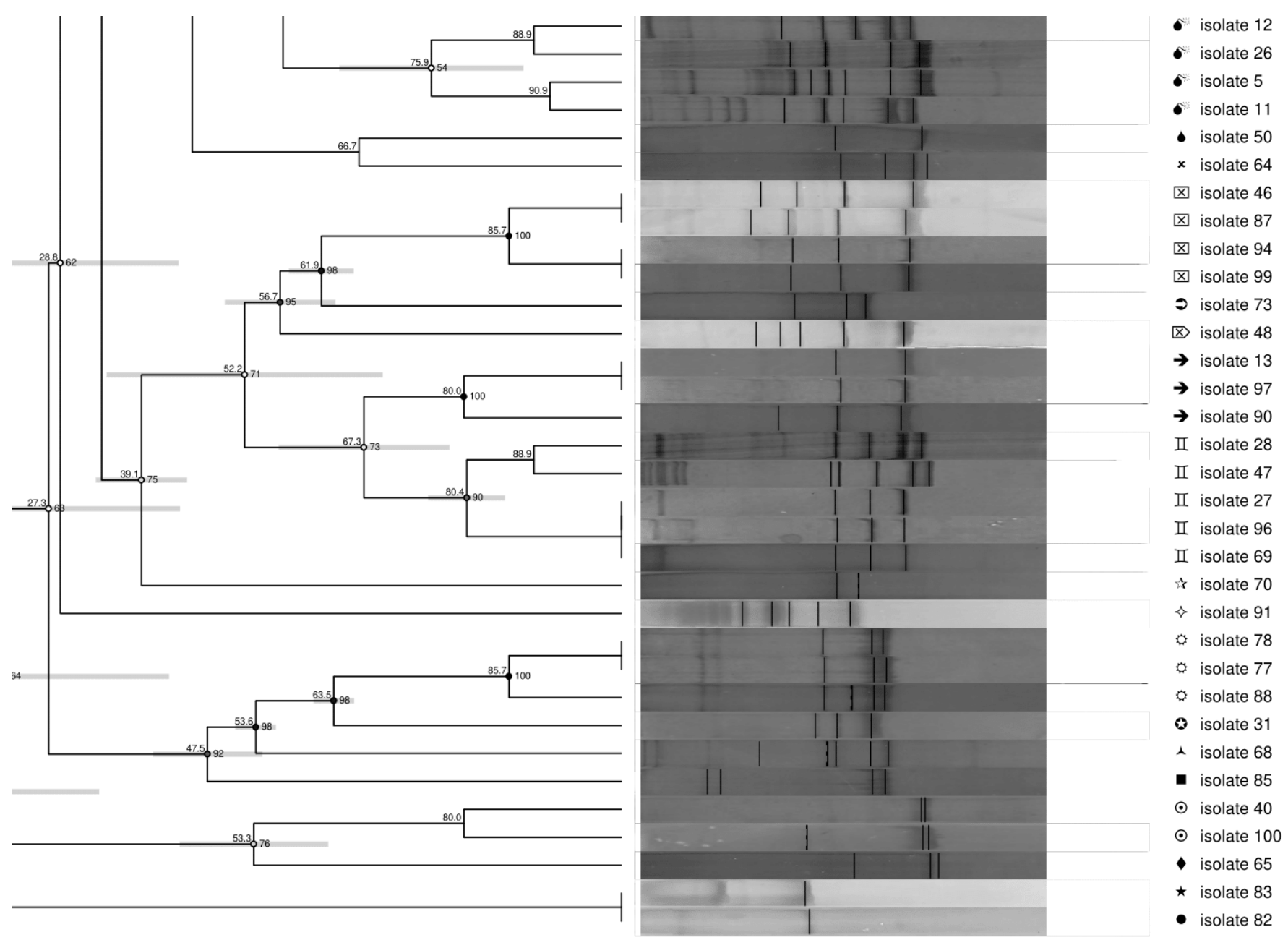

Supplement 1. Cluster analysis of ribosomal intergenic spacer analysis (RISA) banding patterns of bacteria isolated from $\mathrm{PM}_{2.5} \mathrm{Samples}$ filters. Result obtained by the Dice correlation method and the uweighted pair group method using arithmetic averages (UPGMA) similarity coefficient. Symbols at the dendrogram represent the 37 clusters generated with GelCompar II software. 